\title{
1. A framework for the CAP
}

\section{INTRODUCTION}

Since its creation in 1957, the European Economic Community (EEC) has been transformed into the European Union (EU) as a result of a series of treaties extending its competences. What is notable about these treaty changes is that the Title of the original Treaty of Rome on agriculture has not undergone significant amendment. Indeed, its structure has remained basically unchanged. Article 38 of the Treaty on the Functioning of the EU (TFEU) provides for the creation of a Common Agricultural Policy (CAP), the objectives for which are set out in Article 39, with Article 40 providing for the mechanisms of the policy and Article 43 the legislative powers of the institutions to create the policy. Article 4 TFEU provides that agriculture shall be an area of shared competence between the EU and the Member States, which, by virtue of Article 2(2) TFEU, means that both the EU and the Member States may legislate and adopt legally binding acts in this area, with the latter having legislative competence if the EU has not exercised or has ceased to exercise its competence.

The original version of Article 43(1) provided that: 'In order to formulate the guiding lines of a common agricultural policy, the Commission shall... convene a conference of Member States, with a view to comparing their agricultural policies by drawing up, in particular, a statement of their resources and needs.'

In July 1958 the conference was duly convened at Stresa and it concluded that the structure of European agriculture needed to be reformed. ${ }^{1}$ This reform would have to respect the family character of agricultural holdings and European-wide prices would be set at a level slightly above world prices so that farmers would be adequately remunerated without encouraging surplus production and - although not aiming at total self-sufficiency in agricultural

1 For the resolution of the Stresa Conference, see Recueil des documents de la Conférence agricole des Etats membres de la Communauté économique européenne à Stresa du 3 au 12 juillet 1958 (Luxembourg, Service des publications des Communautés européennes, 1958). 
production - Europe would remain open to international trade with measures anticipated to prevent distortions of competition of external origin. Paving the way for the introduction of the CAP, in December 1960 the Council made its first substantive decision on the policy, whose significance rests with its establishment of the three basic principles of the policy. ${ }^{2}$ These provided for the elimination of barriers to trade and distortions of competition between Member States, which would contribute to the common financing of the mechanisms of the policy and Community preference to ensure that the Member States enjoyed the advantages of integration foreshadowed by the Treaty. These principles still lie at the heart of the CAP.

This chapter discusses the Treaty provisions establishing the framework of the CAP. Section 2 examines the objectives of the CAP, looking at both Article 38 - especially the definition of 'agricultural product' - and Article 39. The discussion of the latter also examines the increasing number of demands to which the CAP had to respond as the EEC transformed into the EU and concludes with references to the future objectives of the policy post-2020. Section 3 examines the mechanisms of the policy, beginning with the requirements of Article 40 - in particular, the common organization of agricultural markets and the principle of non-discrimination. There follows a discussion of both Article 41, dealing with vocational training and the promotion of agricultural products, and Article 42 on the rules of competition. As both of these matters are now dealt with in the main instruments of the CAP, this discussion is brief. Section 4 deals with the legislative powers of the institutions. Across all sections, reference is made to the rich jurisprudence of the European courts - the European Court of Justice (now the Court of Justice of the EU) and the Court of First Instance (now the General Court) - which have been so influential in shaping the CAP since its creation. ${ }^{3}$

\section{OBJECTIVES OF THE CAP}

Article 38(2) TFEU provides that 'save as otherwise provided in Articles 39 to 44, the rules laid down for the establishment of the internal market shall apply to agricultural products'. In Ramel the Court declared that: 'The objectives of free movement and of the Common Agricultural Policy should not be set one against the other nor in order of precedence but on the contrary combined and the principle of free movement should prevail save when the special

EC Bull, No 1/61, 83.

Unless otherwise indicated, references to the 'Court' are references to the Court of Justice of the EU rather than the Court of First Instance/General Court. 
requirements of the agricultural sector call for adaptations. ${ }^{4}$ The Commission acknowledged the priority given to the free movement of goods rules in the 1976 case of Commission v France, where it argued that: ${ }^{5}$

the special rules on agriculture cannot, in principle, affect the rules of the Treaty governing the free movement of goods. These rules are binding upon the [EU] legislator in relation to the setting-up of the common agricultural policy... Apart from the case of quite exceptional circumstances, the agricultural provisions of the Treaty do not allow the [EU] institutions the possibility of drawing up measures which do not conform to these rules.

The necessary conclusion from this is that the EU institutions can interfere with the free movement of goods within the EU only in exceptional circumstances. ${ }^{6}$

The CAP to be established under Article 38(4) is to apply to 'agricultural products', which are defined in paragraph 1 as 'the products of the soil, [and] of stock-breeding... as well as products after the first processing stage which are directly connected with such products'; paragraph 3 indicates that these products are listed in Annex I of the Treaty. ${ }^{7}$ The Council was given two years, after the entry into force of the Treaty of Rome, to add to this list and in exercising this power, the Council enacted Regulation $7 \mathrm{a} / 59 .{ }^{8}$ A challenge to the addition of ethyl alcohol by Regulation 7a in König was rejected by the Court, which noted that "the concept of products of "first-stage processing directly related" to basic products must, accordingly, be interpreted as implying a clear economic interdependence between basic products resulting from a productive process, irrespective of the number of operations involved therein'. ${ }^{9}$ As ethyl alcohol had not undergone such processing as to render the price of the agricultural raw materials a marginal cost, it was legitimately included within the scope of Annex I by Regulation 7a. Subsequently, the Court concluded that

Cases 80 and 81/77 [1978] ECR 927, para 19.

Case 68/76 Commission v France [1977] ECR 515, 523.

6 See also, for example, Cases C-157/96 $R v$ Ministry of Agriculture ex parte National Farmers' Union [1998] ECR I-2211; Case C-180/96 United Kingdom $v$ Commission [1998] ECR I-2265; and Case C-293/02 Jersey Produce Marketing Organisation Ltd [2005] ECR I-9543.

Originally referred to as Annex II.

[1961] JO, p 71.

Case 185/73 [1974] ECR 607, 618. The Court also noted:

The definition of agricultural products, placed at the head of the Title devoted to agriculture, would be devoid of practical meaning if it were not to be interpreted, as regards the power of the Council to fill in the gaps with which [Article 38(3)] is concerned, in the light of the aims of the common agricultural policy and with reference to the products with which the authors of the Treaty considered that policy to be concerned. 
the list provided by Annex I as supplemented by Regulation 7a was exhaustive. ${ }^{10}$ However, analysis of Annex I reveals a number of products - such as cheese, margarine and processed fruits - which do not seem to come within the definition offered by Article 38(1); and excludes a number of products - such as cotton, wool and wood - which appear to come within the scope of that paragraph. ${ }^{11}$

For cotton, Protocol 4 of the Greek Treaty of Accession provided for the application of the instruments of the CAP to this product; and the CAP now offers support to cotton production in four Member States. ${ }^{12}$ As for wool, in CILFIT the plaintiffs argued that excluding it from the scope of the CAP would risk disregarding the scope of Article 38(1); but the Commission - supporting the Italian government - pointed to Article 38(3), arguing that the Council had to keep in mind the general definition in paragraph 1 when exercising the power to add to the list. ${ }^{13}$ In this case, the Court noted that: ${ }^{14}$

Since there are no Community provisions explaining the concepts contained in Annex [I] to the Treaty and that annex adopts word for word certain headings of the Common Customs Tariff, it is appropriate to refer to the established interpretations and methods of interpretation relating to the Common Customs Tariff in order to interpret the annex. Annex [I] itself refers moreover to the headings and subheadings of the tariff to identify the products listed.

Examining the Common Customs Tariff, the Court concluded that wool was not included and so fell outside the scope of the CAP. In a subsequent case, using the comment noted above, the Court concluded that 'Annex [I] cannot be regarded as covering in general terms trees and forestry products even though some of those products, taken in isolation, may fall within the scope of Articles 39 to 46 of the Treaty'. ${ }^{15}$ So, Regulations on the protection of forests against atmospheric pollution and against fire could not be adopted with Article 43 as a legal base, as they were not rules on the production and marketing of agricultural products contributing to the attainment of the objectives in Article 39.

These objectives are listed in Article 39(1) as being:

10 Cases 2 and 3/62 Commission v Belgium and Luxembourg [1962] ECR 425.

11 See Case 68/86 UK v Council [1988] ECR 855, in which the Court upheld the use of Article 43 as the legal basis for the administration of hormones to farm animals, even though the hormones were not listed in Annex I. See also Case 123/83 BNIC v Clair [1985] ECR 391 on the inclusion on non-Annex I products if necessary to ensure the success of the common organization of the market in the related Annex I product.

12 See Chapter 2, section 7 for further discussion.

3 Case 77/83 CILFIT [1984] ECR 1257.

14 Ibid, para 7. See also Case 61/80 Stremsel [1981] ECR 851.

15 Cases C-164/97 and C-165/97 Parliament v Council [1999] ECR I-1139, para 18. 
(a) to increase agricultural productivity by developing technical progress and by ensuring the rational development of agricultural production and the optimum utilisation of the factors of production, particularly labour;

(b) thus, to ensure thereby a fair standard of living for the agricultural population, particularly by the increasing of the individual earnings of persons engaged in agriculture;

(c) to stabilise markets;

(d) to assure the availability of supplies; and

(e) to ensure that supplies reach consumers at reasonable prices.

Paragraph 2 of this provision goes on to state that in working out the CAP and its methods, due account shall be taken of 'the particular character of agricultural activities, arising from the social structure of agriculture and from structural and natural disparities between the various agricultural regions; the need to make the appropriate adjustments gradually'; and that 'agriculture is a sector closely linked with the economy as a whole'.

As for the interpretation of these objectives by the Court, one starting point is the decision of the Court in De Samvirkende Danske Landboforeninger, which concerned a decision by the Danish government, following a devaluation of its currency in late 1979, to increase the existing land tax on agricultural property, which led to a rise in agricultural prices. ${ }^{16}$ To the plaintiffs' challenge of the tax as being incompatible with the CAP, the Court replied: ${ }^{17}$

The common agricultural policy was not intended, therefore, to shield those engaged in agriculture from the effects of a national incomes policy. Moreover, the fixing of common prices within the framework of the common organization of markets does not serve to guarantee to agricultural producers a net price independently of any taxation imposed by the national authorities, and the very wording of Article 39 (1) (b) shows that the increase in individual earnings of persons engaged in agriculture is envisaged as being primarily the result of the structural measures described in subparagraph (a).

This conclusion affirms the importance of Article 39(2)(c) - that is, that in working out the CAP, account would be taken of the fact that 'agriculture constitutes a sector closely linked with the economy as a whole'. It was for the national court to decide whether the tax obstructed the common organization of markets; in making that decision, it had to consider that the aim of the price machinery in those organizations was to achieve price levels which took into account the interests of EU production as a whole, the interests of consumers

16 Case 297/82, [1983] ECR 3299.

17 Ibid, para 8. See also Joined Cases 36 and 71/80 Irish Creameries Milk Suppliers Association [1981] ECR 735. 
and a guarantee of supplies, without encouraging over-production. ${ }^{18}$ Article 39(1)(b) is not, therefore, an income guarantee for farmers. ${ }^{19}$ Attempts to tackle the problems caused by surplus production have been characterized by the Court as meeting the objective of paragraph (c), with such stability also being characterized as a means of ensuring the rational development of production, thereby contributing to income stabilization. ${ }^{20}$ As for paragraph (d), the Court made it clear that ensuring 'the availability of supplies' does not require self-sufficiency within the EU. ${ }^{21}$ Finally, with respect to paragraph (e), the Court suggested in Germany v Commission that 'reasonable prices' had to be 'considered in the light of an agricultural policy as laid down by the Treaty and cannot be taken to mean the lowest possible prices'. ${ }^{22}$

No hierarchy of objectives is indicated in Article 39(1). As early as 1968, the Court recognized that the institutions would have to balance the competing demands of Article 39(1) as they could not 'all be realised simultaneously and in full' ${ }^{23}$ In this particular case, Beus, the Court rejected a challenge to the legal basis of the Regulation at issue, which it was alleged, inter alia, interfered with the realization of all the objectives in Article 39 (save guaranteeing the standard of living of producers) and the objectives of the Common Commercial Policy, as then expressed in Article 110 of the Treaty of Rome. The classic formulation of the balancing act to be performed by the institutions occurred in Balkan, a case involving Regulation 974/71, which provided for the application of a system of compensatory amounts in trade with other Member States and third countries, the legal basis for which was Article 103 of the Treaty of Rome on conjunctural policy. ${ }^{24}$ As the system was limited to agricultural markets, the plaintiff argued that Article 103 was an inappropriate legal base and that Articles 40, 43 and 235 of the Treaty of Rome should have been used instead. It further argued that the system infringed Articles 39 and 110 of the same Treaty. In their observations to the Court, both the Council

18 Ibid, para 13. See also para 16, in which the Court noted that account should also be taken of "the rate of the tax, whether it is temporary or permanent, whether or not it affects all agricultural property, whether or not there is a direct link between the amount of the tax and the income of each producer and whether or not the proceeds of the tax were assigned to a specific purpose and if so, what that purpose was'.

19 See, for example, Case 2/75 Mackprang [1975] ECR 607. In Case 281/84 Bedburg [1987] ECR 49 the Court also noted that Article 39(1)(b) could not be interpreted as guaranteeing the processing industry a certain profit margin (para 23).

20 See, for example, Case C-34/08 Azienda Agricola Disarò Antonio [2009] ECR I4203 , para 53.

${ }_{21}$ Case C-353/92 Greece v Council [1994] ECR I-3411, para 40.

22 Case 34/62 [1963] ECR 131, para 25.

23 Case 5/67 [1968] ECR 83, 98.

24 Case 5/73 [1973] ECR 1091. 
and the Commission defended the use of Article 103. The Court concluded that as there was 'no adequate provision' in the CAP allowing for urgent measures to deal with the monetary situation arising from floating exchange rates, the Council was justified in making interim use of Article 103. ${ }^{25}$ The Court also dismissed the argument based on the objectives of the CAP, stating: ${ }^{26}$

In pursuing these objectives the Community institutions must secure the permanent harmonisation made necessary by any conflict between these aims taken individually and, where necessary, allow one of them temporary priority in order to satisfy the demands of the economic factors or conditions in view of which their decisions are made.

This formulation (usually referred to as the 'Balkan formula') has been constantly repeated, with the Court limiting itself to an examination of whether the measure in question contains a manifest error or constitutes a misuse of power, or whether the discretion enjoyed by the institutions has been exceeded. ${ }^{27}$

The Balkan formula suggests that, at some stage, the Court could overrule a measure of the institutions if the situation of 'temporary priority' is continued for a substantial period of time, thus jeopardizing the achievement of the other CAP objectives. This possibility was highlighted in Behla-Mühle, in which the Court used the objectives in Article 39(1) - the principle of non-discrimination in Article 40(2) and the principle of proportionality - to rule that the obligations imposed by the contested Regulation were not necessary to attain the objectives of the CAP. ${ }^{28}$ The Regulation - which was a temporary measure to correct imbalances in the common organization of the market in milk and milk products - imposed not only a financial burden on producers of milk and milk products, but also an obligation on producers in other agricultural sectors to purchase certain quantities of an animal feed product at such a disproportionate price as to constitute a discriminatory distribution of the burden of costs between the various agricultural sectors. Behla-Mühle hinted at the limits to

25 Ibid, 1109.

Ibid, 1112 .

27 See, for example, Case 203/86 Spain v Council [1988] ECR 4563, Case C-280/93 Germany v Council [1994] ECR I-4973 and the repetition of the Balkan formula by the then Court of First Instance (now the General Court) in Case T-489/93 Unifruit Hellas [1994] ECR II-1201.

${ }_{28}$ Case 114/76 [1977] ECR 1211, 1221. 
the latitude afforded to the institutions by the Balkan formula. In the subsequent case of Ludwigshafener Walzmühle, the Court noted: ${ }^{29}$

It should be remembered that, in determining their policy in this area, the competent Community institutions enjoy wide discretionary powers regarding not only establishment of the factual basis of their action but also definition of the objectives to be pursued, within the framework of the provisions of the Treaty, and the choice of the appropriate means of action.

The Court went on to note that the institutions must reconcile the various objectives laid down in Article 39, 'a fact which precludes the isolation of any one of those objectives... in such a way as to render impossible the realization of other objectives'. After repeating the Balkan formula in Crispoltoni II, the Court continued: 'That harmonisation must preclude the isolation of any one of those objectives in such a way as to render impossible the realisation of other objectives.' ${ }^{30}$ At issue in this case was the system of maximum guaranteed quantities in the common organization of the market in tobacco, which it was argued was not appropriate to the objective being pursued, as it did not allow individual quotas to be set. The Court went on to reject allegations that the Regulation breached the principles of proportionality, non-discrimination and protection of legitimate expectations. This case is noteworthy as reform of the tobacco sector would later introduce individual quotas. ${ }^{31}$

While the Court is open to the possibility of interfering with decisions made by the institutions surrounding the CAP's objectives, instances in which it has done so have been rare. This may be a consequence of the fact that the balancing demanded by the Balkan formula emerges not from Article 39(1), but from the nature of agricultural policy, which demands the assessment of complex economic situations. This complexity is recognized in Article 39(2), which acknowledges the particular nature of agricultural activity and that this activity varies between Member States, suggesting that legislation will be both general (covering all of the EU) and specific (reflecting the diversity of conditions between Member States). It should also be noted that Article 39(2)(c) - with its acknowledgement that 'agriculture constitutes a sector closely linked with the economy as a whole' - demands that the wider Treaty objectives also be taken into account. ${ }^{32}$ This particular acknowledgement comes from $U K v$ Council, in which the United Kingdom (UK), supported by Denmark, argued that Directive $85 / 649$ on the use of hormones in beef, which was intended to

\footnotetext{
Joined Cases 197 to 200, 243, 245 and 247/80, [1981] ECR 3211, 3251.

Joined Cases C-133/93, C-300/93 and C-362/93, [1994] ECR I-4863, 4903.

Regulation 2075/92, OJ [1992] L 215/70.

Above n 10, 895.
} 
harmonize the laws of Member States to safeguard the interests and health of consumers, should not have been adopted using only Article 43, as the objectives of the measure were not listed in Article 39. ${ }^{33}$ The Court noted that Article 43 had to be interpreted in the light of both Articles 39 and 40, and that it followed from the second paragraph of Article 39 that 'agricultural policy objectives must be conceived in such a manner as to enable the Community institutions to carry out their duties in the light of developments in agriculture and in the economy as a whole'. It continued: ${ }^{34}$

Efforts to achieve objectives of the common agricultural policy, in particular under common organizations of the markets, cannot disregard requirements relating to the public interest such as the protection of consumers or the protection of the health and life of humans and animals, requirements which the Community institutions must take into account in exercising their powers.

For the Court, there was thus no need to have recourse to another provision of the Treaty as a joint legal basis, as this particular measure contributed to the achievement of one or more of the objectives listed in Article 39.

It was only to be expected that the objectives set for the CAP in the original Treaty - securing a fair standard of living for the agricultural community, stabilizing markets and ensuring reasonable prices for consumers - would be very economically oriented. The Title on Agriculture does make reference to other objectives - namely, rational development of agricultural production, the gradual structural reform of the sector, vocational training of the agricultural workforce and economic development of rural areas. With the transformation of the EEC into the EU, the demands placed on the CAP would shift to the contribution that agriculture could make to a wider variety of economic, social and cultural objectives. This transformation was acknowledged by the Commission in the Agenda 2000 document, which suggested that the CAP's objectives should be reframed, in particular by seeking to improve the competitiveness of EU agriculture, while guaranteeing the safety of food to consumers and ensuring a fair standard of living for the agricultural community. ${ }^{35}$ Beyond these objectives, which are closely tied to the existing objectives, the Commission proposed that the CAP should promote the stability of farm incomes, preserve sustainable farming through the integration of environmental goals, and create complementary or alternative income and employment opportunities for farmers and their families. Overall, the CAP, which would have a more rural than agricultural focus, would contribute to economic cohesion within the EU.

33 Directive 85/649, [1985] OJ L 382/228.

34 Above n 10, para 12.

35 Commission, Agenda 2000 (Brussels, 1997) Ch 3.4. 
Although not fully endorsed in the Agenda 2000 reforms, by 2001 agreement was reached during the European Council meeting in Gothenburg that: ${ }^{36}$ 'the Common Agricultural Policy and its future development should, among its objectives, contribute to achieving sustainable development by increasing its emphasis on encouraging healthy, high quality products, environmentally sustainable production methods, including organic production, renewable raw materials and the protection of biodiversity.'

Adoption of broader objectives for the CAP would occur with the introduction of the Single Payment in the mid-term review, which would promote the objectives of enhancing the competitiveness of EU agriculture, market-oriented sustainable agriculture and rural development. ${ }^{37}$ This would be realized, in part, through the introduction of cross-compliance - that is, Statutory Management Requirements (SMRs) in the areas of the environment, public, plant and animal health, and animal welfare, and the requirement to keep land in good agricultural and environmental condition (GAEC) ${ }^{38}$

The obligation to integrate environmental concerns is now provided in Article 11 TFEU. This mirrors Article 6 of the Treaty of Amsterdam, which was instrumental in the endorsement by the Helsinki European Council in December 1999 of a strategy for integrating the environmental dimension into the CAP, which noted 'the multifunctional role of agriculture from production of food and renewable raw materials to the stewardship of rural landscapes and the protection of the environment'. ${ }^{39}$ It has been noted by the Court that 'with more particular reference to the common agricultural policy and the Community environmental policy, there is nothing in the case-law to indicate that, in principle, one should take precedence over the other' ${ }^{40}$ As for health issues, the Court in $U K v$ Council indicated that the protection of the health and life of humans and animals is a requirement of public interest that should

36 Bulletin of the EU, 6-2001, I 15.

37 See COM (2002) 394.

38 For further discussion of cross-compliance, see Chapter 4, section 2.

39 Available at www.consilium.europa.eu/ueDocs/cms_Data/docs/pressdata/en/ misc/13078.en9.htm. The document continued:

The starting point for the strategy in the agricultural sector is to maintain and promote the model of European agriculture: European agriculture must, as an economic sector, be versatile, sustainable, competitive and spread throughout the territory of Europe, including regions with specific problems. It must contribute to maintaining the countryside, conserving nature, and improving the vitality of rural life, and it must respond to consumer concerns and demands regarding food quality and safety, environmental protection and the safeguarding of animal welfare.

40 Joined Cases C-164/97 and C-165/97 European Parliament v Council [1999] ECR I-1139, para 15. 
be taken into account by the EU institutions in the exercise of their powers. ${ }^{41}$ The Court also referred to consumer protection and this is now reflected in Article 12 TFEU, which provides that 'Consumer protection requirements shall be taken into account in defining and implementing other Union policies and activities'. The need to promote consumer protection arising from various food scares, such as the outbreak of bovine spongiform encephalopathy (BSE) in the UK in the 1980s, was instrumental to the 2002 General Food Regulation laying down the general principles and requirements of food law, establishing the European Food Safety Authority and laying down procedures in matters of food safety. ${ }^{42}$ The second recital of the Preamble to the Regulation provides that 'A high level of protection of human life and health should be assured in the pursuit of Community policies'; while the twelfth recital provides:

In order to ensure the safety of food, it is necessary to consider all aspects of the food production chain as a continuum from and including primary production and the production of animal feed up to and including sale or supply of food to the consumer because each element may have a potential impact on food safety.

As for animal welfare, reference may be made to Article 13 TFEU, which builds on the Protocol on the Protection and Welfare of Animals attached to the Treaty of Amsterdam, which in turn built on the Council of Europe's Convention for the Protection of Animals kept for Farming Purposes laying down minimum common standards for the protection of animals kept for farming purposes. ${ }^{43}$

Beyond the areas covered by cross-compliance, in Germany $v$ Council the Court noted that 'the creation of a common organization of the market requires, alongside the regulation of Community production, the establishment of an import regime to stabilize the markets and ensure sales of Community production if, as in the present case, the internal and external aspects of the

${ }^{41}$ Case 131/86, [1988] ECR 905, para 17. See also Article 168(1) TFEU, which provides that 'a high level of [health] protection shall be ensured in the definition and implementation of all EU policies and activities'; and Case C-146/91 KYDEP v Council and Commission [1994] ECR I-4199.

42 Regulation 178/2002, [2002] OJ L31/1.

43 Article 13 provides:

In formulating and implementing the Union's agriculture, fisheries, transport, internal market, research and technological development and space policies, the Union and the Member States shall, since animals are sentient beings, pay full regard to the welfare requirements of animals, while respecting the legislative or administrative provisions and customs of the Member States relating in particular to religious rites, cultural traditions and regional heritage.

On the Convention, see Council Decision 78/923, [1978] OJ L 323/12. 
common policy cannot be separated' ${ }^{44}$ According to the Court, in the implementation of the CAP, the institutions cannot disregard the EU's international obligations, which in the context of this case were obligations under the Lomé Convention. Article 208(1) TFEU provides that the 'Union shall take account of the objectives of development cooperation in the policies that it implements which are likely to affect developing countries'. The objectives of EU external action are to be found in Article 21(2) of the Treaty on European Union (TEU), which includes the objective of fostering 'the sustainable economic, social and environmental development of developing countries, with the primary aim of eradicating poverty' (paragraph d). Paragraph (e) sets the objective of encouraging 'the integration of all countries into the world economy, including through the progressive abolition of restrictions on international trade'. Development cooperation is an area of shared competence and the 2017 European Consensus on Development recognizes the role that agriculture can play in promoting sustainable development: ${ }^{45}$

Sustainable agriculture... remains a key driver for poverty eradication and sustainable development and is indispensable to ending hunger and ensuring food security. Two thirds of the world's poor depend on agriculture for their livelihoods and a number of developing countries remain highly dependent on trade in a few commodities. Support to smallholders, including family farmers and pastoralists, remains of central importance, contributing substantially to food security and to the fight against soil erosion and biodiversity loss, while providing jobs.

The CAP thus has a role to play in the realization of the 2030 Agenda for Sustainable Development adopted in 2015 by the United Nations General Assembly. ${ }^{46}$ Thus, the November 2017 Commission Communication on the future direction of the CAP includes a commitment to contribute to the UN Sustainable Development Goals. ${ }^{47}$

That Communication also notes the evolution of the CAP to address a range of objectives beyond those listed in Article 39 and sets the following as future objectives: ${ }^{48}$

- to foster a smart and resilient agricultural sector;

- to bolster environmental care and climate action and to contribute to the environmental and climate objectives of the EU; and,

- to strengthen the socio-economic fabric of rural areas.

44 Case 280/93, [1994] ECR I-4973, para 55.

45 See para 55 of the new European Consensus on Development signed on 7 June 2017, available at https://ec.europa.eu/europeaid/sites/devco/files/european-consensus -on-development-final-20170626_en.pdf.

46 See UN General Assembly Resolution, A/RES/70/1.

47 COM (2017) 713, The Future of Food and Farming, p 7.

48 Ibid, $\mathrm{p} 11$. 
At the same time, the policy would continue to add value to a range of other policies, including those on employment, growth and investment, on the Energy Union and the bio-economy, and on migration. Reflecting on the changes that have occurred in the transition from the EEC to the EU in 2010, the Commission noted that although the 'main objectives of the CAP set out in the Treaty of Rome have remained the same over the years', a new policy structure has emerged as the policy has been progressively reformed. ${ }^{49}$ Indeed, when considering Article 39 as a whole, it is possible to read it as encompassing all of the objectives to which the CAP is now expected to contribute.

\section{MECHANISMS OF THE CAP}

Under Article 40, to realize the objectives in Article 39, a common organization of agricultural markets was to be established which could take one of three forms: common rules on competition; compulsory coordination of the various national market organizations; or a European market organization. The choice would depend on the product and would include the measures necessary to attain the objectives set out in Article 39, such as 'aids for the production and marketing of the various products, storage and carryover arrangements and common machinery for stabilising imports or exports'. Article 40 confirms the special position enjoyed by agriculture in the Treaty; and as for the choice to be made in establishing a common organization of the market, that special position would not have been guaranteed if common rules on competition were chosen, as this would have treated agricultural products in the same way as the Treaty treats industrial products. The special position of agriculture therefore demanded a choice between the coordination of national market organizations or the creation of European market organizations. With respect to the choice between these two options, Article 43(4) provides for the replacement of a national market organization by a European market organization if:

(a) the common organisation offers Member States which are opposed to this measure and which have an organisation of their own for the production in question equivalent safeguards for the employment and standard of living of the producers concerned, account being taken of the adjustments that will be possible and the specialisation that will be needed with the passage of time;

(b) such an organisation ensures conditions for trade within the Union similar to those existing in a national market.

49 COM (2010) 672, The CAP towards 2020: Meeting the food, natural resources and territorial challenges of the future, $\mathrm{p} 3$. 
Over time, 21 common organizations were established and each Regulation shared a similar structure, with rules on matters such as intervention, private storage, import tariff quotas, export refunds, safeguard measures, the promotion of agricultural products, state aid rules and the communication and reporting of data. Reform to streamline these regulations was introduced by Regulation 1234/2007, creating a single common organization of the market. ${ }^{50}$ Regulation 1308/2013 now governs this area. ${ }^{51}$

Common organizations of the market were to be established by the end of the transitional period and if such organizations were not established, questions were raised about the legal status of any national organization of the market. It was assumed that such organizations would be protected until replaced by a common organization and the Court addressed this in Charmasson, in which the plaintiff argued that France had violated the provisions of the Treaty (and the Yaoundé Convention) by applying a quota system for importation of bananas into France. The starting point for the Court was to offer the following as the definition of a 'national market organization': 52

a totality of legal devices placing the regulation of the market in the products in question under the control of the public authority, with a view to ensuring, by means of an increase in productivity and of optimum utilisation of the factors of production, in particular manpower, a fair standard of living for producers, the stabilisation of markets, the assurance of supplies and reasonable prices to the consumers.

National market organizations were therefore to have objectives equivalent to those of the CAP. ${ }^{53}$ A simple quota system, such as existed in Charmasson, could not therefore amount to a national market organization. Turning to the question of the impact of the end of the transitional period on such organizations, the Court concluded that before the end of this period, the national organization must adapt itself to the fullest extent possible to the requirements of the internal market. ${ }^{54}$ It continued: "Accordingly, the derogations which

50 [2007] OJ L 299/1.

51 For further discussion of Regulation 1308/2013, see Chapter 5.

52 Case 48/74 [1974] ECR 1383, 1396. This mirrors the definition offered by the Court in 1964 when it stated: 'a market organisation is a combination of legal institutions and measures on the basis of which appropriate authorities seek to control and regulate the market.' Cases 90 and 91/63 Commission v Luxembourg and Belgium [1964] ECR 625, 635.

53 In Case 237/82 Kaas [1984] ECR 483 the Court noted that in those areas where the Member States remain competent, the exercise of their powers must respect the objectives of Article 39(1).

54 It must be noted here that in a competition decision, New Potatoes, the Commission held that the objectives of the national market organization must be equivalent to those pursued by common organizations of the market ([1988] OJ L 262/27). 
a national organisation may effect from the general rules of the Treaty are only permissible provisionally, to the extent necessary to ensure its functioning, without however impeding the adaptations which are involved in the establishment of the common agricultural policy.' ${ }^{55}$ As that policy was to enter into force at the end of the transitional period, any national market organizations in existence after that time would become subject to the general rules of the Treaty.

The ruling of the Court in Charmasson was confirmed in Commission v France, a case concerning restrictions on the exports of potatoes from France. ${ }^{56}$ It was also forcefully restated in Commission v Ireland, where the Court stated: 'agricultural products in respect of which a common organisation of the market has not been established are subject to the general rules of the [internal] market with regard to importation, exportation and movement within the [EU]. ${ }^{57}$ Although this makes it clear that the free movement of goods rules apply to national market organizations, problems arose in the area of competition policy. These problems were recognized in Commission v France, where the Court suggested that there was nothing to prevent France from implementing a scheme of national aids in the sheep meat sector pending the establishment of a common organization of the market in that product. ${ }^{58}$ State aid for potatoes, for which there is still no common organization of the market, was specifically endorsed in the decision of the Court in SICA. ${ }^{59}$

55 Above n 52, 1395. Article 44 provides:

Where in a Member State a product is subject to a national market organisation or to internal rules having equivalent effect which affect the competitive position of similar production in another Member State, a countervailing charge shall be applied by Member States to imports of this product coming from the Member State where such organisation or rules exist, unless that State applies a countervailing charge on export. The Commission shall fix the amount of these charges at the level required to redress the balance; it may also authorise other measures, the conditions and details of which it shall determine.

See Case 337/82 St Nikolaus Brennerei [1984] ECR 1051 for an interpretation of this provision.

56 Case 68/76 [1977] ECR 515. See also Case 231/78 Commission v UK [1979] ECR 1447, which discussed Article 60(2) of the Act of Accession (i.e. non-application of the rules on the free movement of goods in respect of products not covered by a common organization of the market on the date of accession, but for which a national market organization existed at that time), for which no time limit had been set for its expiry. As a result of this ruling, the equivalent provision in the Greek Act of Accession (Article 65(2)) and subsequent Acts of Accession set dates by which the provision would cease to apply. See Cases 194 and 241/85 Commission v Greece (Bananas) [1988] ECR 1037.

57 Case 288/83 [1985] ECR 1761, 1774.

58 See Case 232/78 Commission v France [1979] ECR 2729.

59 Case 114/83 [1984] ECR 2589. 
One question that arises in this context is the power of the Member States whenever there is a common organization of the market. In Galli, in which the issue was the power of the Member States - in this case, Italy - to impose price controls, the Court noted: 'So as to ensure the freedom of internal trade the regulation comprises a set of rules intended to eliminate both the obstacles to the free movement of goods and all distortions in intra-[EU] trade due to market intervention by Member States other than that authorised by the regulation itself.' ${ }^{60}$ In the opinion of the Court, in sectors covered by a common organization of the market, unilateral measures interfering with the mechanisms of price formation within the common organization were no longer possible. However, interference by the Member States with the formation of prices at other stages in the marketing process was found to be acceptable. ${ }^{61}$ The Court pointed out in Van den Hazel: 'Once the [EU] has, pursuant to Article 40 of the Treaty, legislated for the establishment of the common organisation of the market in a given sector, Member States are under an obligation to refrain from taking any measure which might undermine or create exceptions to it. ${ }^{62}$ Subsequent cases have confirmed this principle and, indeed, extended it to include the principles underlying, and the provisions establishing, the common organization. ${ }^{63}$ So, the existence of a common organization of the market precludes national legislation on matters covered by the common organization.

Nevertheless, national legislation that either is anticipated by the common organization of the market or pursues objectives different from those of the common organization may still be permissible. ${ }^{64}$ In the latter case, the Court has held that the existence of a common organization of the market does not

\footnotetext{
60 Case 31/74 [1975] ECR 47, 61. See also Case 4/79 Providence Agricole v ONIC [1980] ECR 2823.

${ }_{61}$ See, for example, Case 66/75 Tasca [1976] ECR 291, Case 10/79 Toffoli [1979] ECR 3301 and Cases 16-20/79 Danis [1979] ECR 3327.

62 Case 111/76 [1977] ECR 901, 909. See also Case 50/76 Amsterdam Bulb [1977] ECR 137, Case 218/85 Cerafel [1986] ECR 3513 and Case C-132/95 Jensen [1998] ECR I-2975.

${ }_{63}$ See, for example, Case C-32/89 Greece v Commission [1991] ECR I-1321. The principle also applies even if the unilateral measures were to support the common policy; see Case 90/86 Zoni [1988] ECR 4285.

${ }_{64}$ See Case 16/83 Prantl [1984] ECR 1299 and Case 48/85 Commission v Germany [1986] ECR 2549.
} 
exempt producers from following national legislation that pursues different objectives from the common organization. ${ }^{65}$ In Holdijk the Court held that: ${ }^{66}$

the establishment of such an organisation pursuant to Article 40 of the Treaty does not have the effect of exempting agricultural producers from any national provisions intended to attain objectives other than those covered by the common organisation, even though such provisions may, by affecting the conditions of production, have an impact on the volume or the cost of national production and therefore the operation of the [internal] market in the sector concerned.

Given the absence at that time of EU legislation on the protection of animals, and pending the adoption of such legislation, the Court upheld the validity of Dutch measures laying down minimum requirements for keeping fatting calves in enclosures. In Pluimveeslachterij Midden-Nederland the Court rejected the argument that Dutch legislation on the packaging and slaughtering of poultry was not permissible under the common organization of the market, especially as the Regulation establishing that organization had anticipated such legislation. ${ }^{67}$ Such legislation had been proposed, but never enacted; and with regard to the nature of the national measures pending the enactment of EU measures, the Court stated: ${ }^{68}$

such measures may not be regarded as involving the exercise of the Member State's own power, but as the fulfilment of the duty to co-operate in achieving the aims of the common organisation of the market which, in a situation characterised by the inaction of the $[\mathrm{EU}]$ legislature, Article 5 of the Treaty imposes on them.

The legislation, which the Court characterized as temporary and provisional in nature, would cease to apply once the EU legislated in the particular area. It is more usual for national legislation which interferes with the operation of a common organization to be held as unacceptable. For example, in Apple and Pear Development Council, this particular body could not lay down quality standards for fruit - a matter covered by the common organization of the market in fruit and vegetables; but it could give advice on quality, a matter not covered by that organization. ${ }^{69}$ Likewise, in Commission v France (Milk Substitutes), the Court held that a French measure prohibiting the sale of substitute milk powder was contrary to the Treaty, for although it supported the

\footnotetext{
65 See, for example, Case 118/86 Nertsvoederfabriek [1987] ECR 3383.

${ }_{66}$ Case 141-143/81 [1982] ECR 1299, 1313-1314.

67 Cases 47 and 48/83 [1984] ECR 1721.

68 Ibid, 1738. In Case 804/79 Commission v United Kingdom [1981] ECR 1045 the Court considered the Member States to be the 'trustees of the common interest' in this situation.

${ }_{69}$ Case 222/82 [1983] ECR 4083. See also Case 218/85 Cerafel [1986] 3513.
} 
$\mathrm{CAP}$, it ran counter to the principle of free movement of goods. ${ }^{70}$ An attempt to justify the measure by pointing to the then surplus of this product in the EU was rejected by the Court, which pointed out that the elimination of surpluses was an EU responsibility.

In addition to suggesting a range of measures in a common organization of the market to attain the objectives in Article 39, Article 40(2) provides that the 'common organisation shall be limited to pursuit of the objectives set out in Article 39 and shall exclude any discrimination between producers or consumers within the Union'. In the application of the principle of non-discrimination, the Court has indicated that in particular circumstances, differences in treatment may not amount to discrimination or may be objectively justified. ${ }^{71}$ One interesting case in this area is Royal Scholten Honig, in which a Regulation freezing and eliminating production refunds for various starches used in the manufacture of isoglucose and introducing production levies on the manufacture of isoglucose was challenged by a number of isoglucose manufacturers. ${ }^{72}$ The Court pointed out that Article 40(2) was 'merely a specific enunciation of the general principle of equality', which was one of the fundamental principles of EU law. Interestingly, the Court went on to examine the situation not of producers, but of products - that is, the situation of isoglucose compared with other products of the starch industry - and found no discrimination. However, it did find that isoglucose and sugar were in a comparable position and concluded that the provisions of the Regulation on the production levy were contrary to Article 40(2).

The approach of the Court in this case has been followed in numerous instances. The Court first establishes whether the products (or producers) between which there is alleged discrimination are in a comparable (competing) situation; if so, it moves on to establish whether there is a difference in treatment and, if so, whether such difference can be objectively justified, with the burden of proof falling not on the producers, but on the institutions. ${ }^{73}$ Although the principle mentions only producers and consumers, it has been extended to all operators (e.g. importers and exporters) ${ }^{74}$

70 Case 216/84 [1988] ECR 793.

71 See, for example, Case C-354/95 National Farmers' Union [1997] ECR I-4559, para 61, Case C-152/09 Grootes [2010] ECR I-11285, para 66 and Case C-401/11, Soukupová (Judgment of 11 April 2013) available at https://eur-lex.europa.eu/legal -content/EN/TXT/PDF/?uri=CELEX:62011CJ0401\&rid=6, para 31.

72 Cases 103 and 145/77 [1978] ECR 2037.

73 See, for example, Case 8/82 Wagner [1983] ECR 371, Case 58/86 Coopérative agricole d'approvisionnement des Avirons [1987] ECR 1423 and Case C-309/89 Codorniu [1994] ECR I-1853.

74 See, for example, Case 165/84 Krohn [1985] ECR 3997 and Case C-280/93 Germany v Council [1994] ECR I-4973. 
Article 40(2) is also usually read as requiring the application of the principle of proportionality. This principle, along with a number of other legal principles, was raised in $R v$ Minister of Agriculture, Fisheries and Food and Secretary of State for Health, ex parte Fedesa, in which questions were raised about the validity of Directive $88 / 146$ prohibiting the use in livestock farming of certain hormones. ${ }^{75}$ The Court defined the 'principle of proportionality' as follows: ${ }^{76}$

the lawfulness of the prohibition of an economic activity is subject to the condition that the prohibitory measures are appropriate and necessary in order to achieve the objectives legitimately pursued by the legislation in question; when there is a choice between several appropriate measures recourse must be had to the least onerous, and the disadvantages caused must not be disproportionate to the aims pursued.

In this case, the principle of proportionality had not been infringed. On the issue of whether the Directive breached the principle of legal certainty, the Court noted that this principle requires 'any measure adopted by the Community institutions to be founded on a rational and objective basis', with judicial review being limited to 'examining whether the measure in question is vitiated by a manifest error or misuse of powers, or whether the authority in question has manifestly exceeded the limits of its discretion' ${ }^{77}$

The Court has consistently noted that in matters concerning the CAP, the institutions have a discretionary power which corresponds to the political responsibilities given to them by Article 40 TFEU (and Article 43 TFEU). So, a measure will be overruled only if it is manifestly inappropriate having regard to the objective which the institutions are seeking to pursue. ${ }^{78}$ This is well illustrated by the case-law on compensatory amounts which were introduced in the aftermath of the currency crisis of 1971 and the floating of the exchange rates of all the Member States. The system of monetary compensatory amounts was incorporated into the CAP by Regulation 2746/72, which rendered their application compulsory in certain cases. ${ }^{79}$ In the aftermath of the first enlargement

75 Case C-331/88, [1990] ECR I-4203. As the Court noted in Philip, 'in order to establish whether a provision of Community law complies with the principle of proportionality, it is necessary to ascertain whether the means which that provision applies to achieve its aim correspond to the importance of that aim and whether they are necessary in order to achieve it'. Case C-155/89 [1990] ECR I-330, para 34.

76 Ibid, para 13.

77 Ibid, para 8. See also Case 1/73 Westzucker [1973] ECR 723 involving an overlap of the principle of legal certainty with the principle of protection of legitimate expectations.

78 See, for example, Case 265/87 Schraeder [1989] ECR 2237.

79 [1972] JO L 291/48. The legal basis of this measure included Article 43. 
and the decision of the United States government to float the dollar, further changes were made to the system with the introduction of green currency rates. ${ }^{80}$ The system generated considerable activity before the Court, which recognized that the system of monetary compensatory amounts was a breach of the principle of market unity, but also acknowledged that this unity would result not only from the operation of the CAP, but also from the coordination of the economic and monetary policy of the Member States. ${ }^{81}$ In Schlüter, the Court noted that: 'Diversion of trade caused solely by the monetary situation can be considered more damaging to the common interest bearing in mind the aims of the Common Agricultural Policy, than the disadvantage of the measures in dispute. ${ }^{82}$ It also noted that the system was designed to protect the European market rather than national markets or the individual interests of traders, and concluded that the institutions could be held liable for damage to the legitimate expectations of traders only if it were to abolish or modify the monetary compensatory system immediately without adopting transitional measures and a prudent trader could not reasonably foresee such abolition or modification ${ }^{83}$ Given the nature of the complex monetary difficulties faced by the institutions during this period, it was rare for the Court to overrule the exercise of the discretion by the institutions in their responses to these difficulties. ${ }^{84}$

Article 40(3) provides: 'In order to enable the common organisation referred to in paragraph 1 to attain its objectives, one or more agricultural guidance and guarantee funds may be set up.' Regulation 25 established a single fund forming part of the EU budget from which export refunds and intervention purchases would be financed and into which the revenue from import levies would be paid. ${ }^{85}$ In 1964, the Fund was split into two sections: a Guarantee Section, which would relate to the various aspects of the market and price

80 See, for example, Regulation 222/73, [1973] OJ L 27/4 (on the creation of representative rates for the UK and Ireland), Regulation 112/73, [1973] OJ L 114/4 (on the introduction of an agreement by some Member States (the 'snake') to limit currency fluctuations within fixed margins) and Regulation 475/75, [1975] OJ L 52/28 (on the introduction of green currencies).

81 See, for example, Case 10/73 Rewe [1973] ECR 1175, Case 43/72 Merkur [1973] ECR 1055 and Cases 70 and 81/77 Ramel [1978] ECR 927. For comments on some of this jurisprudence, see Usher J 'Agricultural Markets: Their Price Systems and Financial Mechanism' (1979) 4 ELRev 147 and Gilsdorf P 'The System of Monetary Compensatory Amounts from a Legal Standpoint' (1980) 5 ELRev 341 and 433.

82 Case 9/73 [1973] ECR 1135, 1159.

83 See, for example, Case 97/76 Merkur [1977] ECR 1063 and Case 146/77 British Beef [1978] ECR 1347. See also Case 74/74 CNTA [1975] ECR 533.

${ }_{84}$ See, for example, Case 108/77 Wagner [1978] ECR 1187, Case 131/77 Milac [1978] ECR 1041 and Case 4/79 Providence Agricole [1980] ECR 2823.

85 [1962] JO 30, 991. 
policy followed by the EU; and a Guidance Section, which would relate primarily to the measures needed to implement the structural policy of the EU. ${ }^{86}$ After the end of the transitional period, Regulation 729/70 confirmed the existence of the European Agricultural Guidance and Guarantee Fund as part of the EU budget. ${ }^{87}$ Further reforms have followed - notably Regulation 1290/2005, which created two funds (the European Agricultural Guarantee Fund and the European Agricultural Fund for Rural Development) operating under a single management and control system. ${ }^{88}$ The current Regulation in this area is Regulation 1306/2013. ${ }^{89}$

Article 41 provides for a number of other measures to attain the objectives in Article 39 - in particular, 'an effective coordination of efforts in the spheres of vocational training, of research and of the dissemination of agricultural knowledge' and 'joint measures to promote consumption of certain products'. Education is an important element in the rural development policies of the Member States. ${ }^{90}$ As for the promotion of agricultural products, Regulation $3 / 2008$ put in place an information and promotion policy for agricultural products, but was the subject of a negative report from the Court of Auditors. ${ }^{91}$ In response, the Commission published a Green Paper on the promotion of agricultural products in 2011 and a further communication in 2012 to simplify and improve the policy framework. ${ }^{92}$ The latter concluded that reform of the CAP 'needs to be accompanied by a promotion policy that makes it possible to deploy the entire potential of the food sector in order to favour growth and employment within the European economy'. ${ }^{93}$ The new promotion policy may be found in Regulation 1144/2014, which sets the objectives of the information provision and promotion measures as being to: ${ }^{94}$

(a) increase awareness of the merits of Union agricultural products and of the high standards applicable to the production methods in the Union;

86 Regulation 17/64, [1964] JO 586.

[1970] JO L 94/13.

[2005] OJ L 209/1.

89 For further discussion of this Regulation, see Chapter 4.

90 For further discussion, see Chapter 3.

91 [2008] OJ L 3/1. See Special Report of the Court of Auditors No 10//2009 Information provision and promotion measures for agricultural products, paras 53-57.

92 COM (2011) 436 Green Paper on promotion measures and information provision for agricultural products: a reinforced value-added European strategy for promoting the tastes of Europe and COM (2012) 148.

$93 \mathrm{COM}$ (2012) 148, p 11.

94 [2014] OJ L 317/46, Article 2(2). See also Commission Delegated Regulation 2015/1829, [2015] OJ L 266/3 and Commission Implementing Regulation 2015/1831, [2015] OJ L 266/14. 
(b) increase the competitiveness and consumption of Union agricultural products and certain food products and to raise their profile both inside and outside the Union;

(c) increase the awareness and recognition of Union quality schemes;

(d) increase the market share of Union agricultural products and certain food products, specifically focusing on those markets in third countries that have the highest growth potential;

(e) restore normal market conditions in the event of serious market disturbance, loss of consumer confidence or other specific problems.

Eligible products are defined in Article 5 of the Regulation as including those listed in Annex I TFEU (excluding tobacco), Annex I to the Regulation (e.g. beer, chocolate, bread, pasta and cotton), and spirits with a protected geographical indication under Regulation 110/2008.

The 2018 Work Programme to implement Regulation 1144/2014 offers $€ 11$ million to enhance awareness of the EU's quality schemes, with the aim of increasing consumer recognition of the logos associated with such schemes. ${ }^{95}$ A further $€ 7$ million is to be made available to highlight at least one of the specific features of EU agricultural production methods (e.g. in terms of food safety, nutritional and health aspects, animal welfare, and respect for the environment and sustainability), so as not only to increase consumer awareness of the merits of EU agricultural products in these areas, but also to enhance the competitiveness and consumption of EU agri-food products. A final example of measures within the EU is the $€ 2$ million which will be made available in the sheep/goat meat sector, in which consumption has been declining and EU production faces strong competition from imports, which will highlight the environmental sustainability of EU production in this sector, leading to greater consumer awareness of the merits of EU production. ${ }^{96} \mathrm{~A}$ total of $€ 75$ million will be available for information provision and promotion programmes targeting one or more third countries. ${ }^{97}$ In total, in 2018, grants of just over $€ 188.6$ million will be available to implement Regulation 1144/2014, with the EU's contribution to programmes submitted from organizations in one Member State to be at least 70 per cent, rising to 80 per cent for programmes submitted from organizations in at least two Member States. A special co-financing rate

95 See https://ec.europa.eu/info/sites/info/files/c_2017_7475_2_annex_en_v3_p1 953657.pdf, Table 1.2.1.1. A further $€ 30$ million is available for programmes in this area; see Table 1.2.1.3.

96 Ibid Table 1.2.1.3, under which a further $€ 4$ million is made available for information provision and promotion programmes aimed at highlighting the sustainable aspect of sheep/goat meat production.

${ }_{97}$ Ibid, Table 1.2.1.2. €26.25 million is for programmes targeting China, Japan, South Korea, Taiwan, Southeast Asia or the Indian subcontinent, with $€ 22.5$ million allocated to programmes in Canada, the United States, Mexico and Colombia. 
of 85 per cent applies to programmes responding to serious market disturbance, loss of consumer confidence or other specific problems. ${ }^{98}$

In response to a complaint by Germany that aspects of Regulation 404/93, which established the common organization of the market in bananas, breached the principle of undistorted competition, the Court noted that although this was an EU objective, so too was the establishment of the CAP. ${ }^{99}$ The Court noted that the authors of the Treaty were aware of this conflict - hence Article 42(1), which provides:

The provisions of the Chapter relating to rules on competition shall apply to production of and trade in agricultural products only to the extent determined by the Council within the framework of Article 43(2) and (3) and in accordance with the procedure laid down therein, account being taken of the objectives set out in Article 39.

The Council made the determination provided for in Article 42 through the enactment of Regulation 26, allowing the EU competition rules to apply with certain exceptions to the agricultural sector. ${ }^{100}$

One of these exceptions was Article 2, whereby an agreement for which exemption from the competition provisions is sought must satisfy all the objectives of the CAP. This provision was at issue in Frubo, in which the Court was asked to annul a Commission decision that Frubo's agreement infringed the competition provisions of the Treaty, on the basis that it infringed not only Article 2 of Regulation 26, but also Articles 39, 40 and 85 of the Treaty of Rome. ${ }^{101}$ Frubo argued that its agreement met three of the objectives set out in Article 39(1):

- to stabilize markets;

- to assure the availability of supplies; and

- to ensure that supplies reach consumers at reasonable prices.

In response, the Court noted that the applicant had not shown how its agreement was necessary to realize the objectives in Articles 39(1)(a) and (b), so the Commission was correct in deciding that Article 2 of Regulation 26 was inap-

98 Ibid, $\mathrm{p} 2$. The total allocation is split $€ 100$ million for simple programmes (i.e. involving one Member State), €79.1 million for multi programmes (i.e. involving at least two Member States) and $€ 9.8$ million for initiatives by the Commission.

99 Case C-280/93 Germany v Council [1994] ECR I-4973, para 59.

100 [1962] JO 30, 993.

101 Case 71/74 [1975] ECR 563. 
plicable. The Court followed the approach taken by Advocate General Warner, whose opinion noted the fallacy underlying Frubo's argument: ${ }^{102}$

The fallacy is that Article 2 confers on the parties to an agreement the right to claim exemption for any restriction it contains if only they can show that, in relation to the market in any agricultural product, the restriction conduces to the attainment of one or some of the objectives set out in Article 39 of the Treaty. The argument overlooks that the objectives set out in Article 39 are those of the common agricultural policy and that, as such, they relate to Community agriculture and are inseparable from each other.

For the Advocate General and the Court, an agreement can be exempted from the competition provisions if it is designed and necessary to secure all the objectives listed in Article 39(1). ${ }^{103}$ So although there are limits to the application of competition law to agriculture, the application of competition law cannot be totally excluded - a conclusion recognized by the Court in Milk Marque, in which the common organizations of the market were described as 'not a competition-free zone'. ${ }^{104}$

The single common organization of the market regulation, Regulation $1308 / 2013$, now contains competition rules applying to undertakings and State aid rules. ${ }^{105}$ The rules apply only to products listed in Annex I, so in BNIC v Clair, the Court held that cognac was an industrial product and rejected an argument for special treatment based on the regional economic importance of the product. ${ }^{106}$ Similarly, in BNIC v Aubert the Court found brandy to be an industrial product, and that it did not matter that the levies collected by BNIC were in part used to finance measures to support wine, an Annex I product. ${ }^{107}$ So the first question to be answered in an enquiry into the application of the

102 Ibid, 594.

103 See, for example, Bloemenveilingen Aalsmeer ([1988] OJ L 262/27), a Commission Decision granting negative clearance to decisions and agreements between the various groups of producers which formed an integral part of the French national market organization. Changes to these agreements led to Joined Cases T-70/92 and T-71/92 Florimex and VGB [1997] ECR II-693 and Case T-77/94 VGB [1997] ECR II-759.

104 Case C-137/00, [2003] ECR I-7975, para 59. See also Case T-39/06 Transcatab [2011] ECR II-6831, paras 300-304.

105 For a fuller discussion, see Chapter 5, section 3.

106 Case 123/83 [1985] ECR 391. In 1976 the Commission had decided that armagnac was an industrial product; Pabst and Richarz/BNIA OJ 1976 L 231/24.

107 Case 136/86 [1987] ECR 4789. See also Case 61/80 Stremsel [1981] ECR 851, where the Court concluded that rennet, an enzyme used in the manufacture of cheese, was not included in Annex I, so Regulation 26 could not be used to excuse an exclusive purchasing obligation. See also Case T-61/89 Dansk Pelsdyravlerforening [1992] II-ECR 1931 and Case C-250/92 Gottrup-Klim [1994] ECR I-5641. 
competition rules is whether the product at issue is listed in Annex I. If so, Regulation 1308/2013 will apply; if not, the competition rules of the Treaty apply (national competition law may also apply). ${ }^{108}$ In $F N C B V$ the Court of First Instance, having referred to the jurisprudence on undertakings in the context of competition law (i.e. any activity consisting of offering goods and services in a given market is an economic activity), concluded that the activity of farmers was of an economic nature, so they constituted undertakings for the purposes of the application of the competition provisions. ${ }^{109}$

These provisions also include the Merger Regulation, under which the Commission has issued a number of decisions in relation to agriculture. ${ }^{10}$ An early Commission decision approved a proposed concentration, subject to compliance with a series of commitments, in 2000 with respect to the merger of Danish Crown and Vestjyske Slagterier, respectively the largest and second largest cooperative slaughterhouses in Denmark. ${ }^{111}$ Since then, most of the decisions have been ones of non-opposition - although the proposed merger of Campina and Friesland Foods in the Netherlands was approved subject to conditions, as was the merger of Syngenta and Monsanto's sunflower seed business. ${ }^{112}$ The Commission has also approved a joint venture between two Brazilian companies, Votorantum and Fischer, which was notified as falling within the scope of the Regulation as they would have an EU turnover in excess of $€ 250$ million, but they did not realize more than two-thirds of this turnover within one Member State. ${ }^{113}$ More recently, in 2018 the Commission give conditional clearance to Bayer's planned acquisition of Monsanto, subject to a divestment package to address competition concerns in seeds, pesticides

108 See also Regulation 1184/2006, [2006] OJ L 214/7. See, for example, Case C-505/07 Compañía Española de Comercialización de Aceite SA [2009] ECR I-8963, paragraphs $51-58$.

109 Case T-217/03 and T-245/03 [2006] ECR II-4987, paras 52-55.

110 See Regulation 139/2004, [2004] OJ L 24/1 and its predecessor, Regulation 4064/89, [1989] OJ L 395/1. As for the merger decisions, see, for example, Case No IV/M Zeneca/Vanderhave [1996] OJ C 188/10, Case No IV/M.720 Cereol Aceprosa [1996] OJ C 266/9 and Case No IV/M.1420 BASF/Svalöf Weibull [1999] OJ C 74/6.

111 See Decision 2000/42 [2000] OJ L 20/1, (Case IV/M.1313). Recitals 200 to 233 set out the commitments.

112 [2009] OJ C 75/21 (Case No COMP/M.5046 — Friesland Foods/Campina) and Case No COMP/M. 5675 - Syngenta/Monsanto's Sunflower Seed Business, text available at http://ec.europa.eu/competition/mergers/cases/decisions/m5675_20101117 _20600_1556193_EN.pdf.

113 See Commission Decision of 4 May 2011 in Case COMP/M.5907, details of which are available at http://ec.europa.eu/competition/mergers/cases/decisions/m5907 _20110504_20682_1898514_EN.pdf. 
and digital agriculture; and, subject to conditions, the acquisition by BASF of a number of businesses in these areas of concern. ${ }^{114}$

\section{LEGISLATIVE POWERS}

Under Article 43(1) TFEU, it is the Commission's responsibility to 'submit proposals for working out and implementing the common agricultural policy', with the following two paragraphs providing:

2. The European Parliament and the Council, acting in accordance with the ordinary legislative procedure and after consulting the Economic and Social Committee, shall establish the common organisation of agricultural markets provided for in Article 40(1) and the other provisions necessary for the pursuit of the objectives of the common agricultural policy and the common fisheries policy. ${ }^{115}$

3. The Council, on a proposal from the Commission, shall adopt measures on fixing prices, levies, aid and quantitative limitations and on the fixing and allocation of fishing opportunities.

The original version of Article 43(2) gave sole legislative power to the Council, with a requirement to consult only the European Parliament. ${ }^{116}$ Failure to consult the European Parliament was declared by the Court to be a breach of an essential procedural requirement in Roquette, in which it noted that the requirement was not satisfied by simply asking for the European Parliament's opinion, but was satisfied when the European Parliament expressed its opinion. ${ }^{117}$ The principles from this line of jurisprudence now apply only to consultation with the Economic and Social Committee. The Council, however, retains sole legislative power under Article 43(3) to adopt measures

114 For further details see http://europa.eu/rapid/press-release IP-18-2282 en.htm (21 March 2018) and http://europa.eu/rapid/press-release_IP-18-3622_en.htm (30 April 2018).

115 Article 43 also extends to measures concerning trade in agricultural products; see Cases 51-54/71 International Fruit [1971] ECR 1107, Cases 3, 4 and 7/76 Kramer [1976] ECR 1279 and Opinion 1/94 [1994] ECR I-5276.

116 For a discussion of the extension of co-decision to agriculture, see, for example, Roederer-Rynning $\mathrm{C}$ and Schimmelfennig F, 'Bringing co-decision to agriculture: a hard case of parliamentarization' (2012) 19 Journal of European Public Policy 951.

117 Case 138/79, [1980] ECR 3333, 3360-3361. See also Case C-45/93 European Parliament $v$ Council [1995] ECR I-643 on the European Parliament's duty of loyal cooperation, suggesting that it may not delay giving an opinion on proposals which are a matter of urgency. 
in a limited number of areas and this raises the question of the dividing line between the two paragraphs. ${ }^{118}$

On 7 September 2016, the Court gave its judgment in a case brought by Germany seeking the partial annulment of Regulation 1308/2013, arguing that this provision should have been adopted under Article 43(3). ${ }^{119}$ The provision at issue was Article 7, which fixed reference thresholds in the cereals sector, for paddy rice, for sugar and various products in the beef and veal, milk and milk products, pig meat and olive oil sectors; the thresholds were to be kept under review by the Commission and could be updated using the ordinary legislative procedure. ${ }^{120}$ The Regulation had been adopted under Article 43(2), but Germany had voted against its adoption, arguing that Article 7 fell within the exclusive competence of the Council under Article 43(3) as it included measures related to 'fixing prices', and that adoption of the measure under Article 43(2) would render Article 43(3) meaningless. ${ }^{121}$ This argument was supported by the Czech Republic and the UK, with the former arguing that 'Article 43(3) TFEU constitutes a lex specialis in relation to the broader measures referred to in Article 43(2) TFEU', and that there was evidence that 'the Member States wished to remain sovereign concerning the costs of the CAP'. ${ }^{122}$ In contrast, the Parliament argued that Article 43(3) conferred a very specific executive power on the Council to fix the exact final amounts of the prices, so any measure beyond the fixing of prices fell under Article 43(2); paragraph 3 was thus an exception to the general rule laid down in paragraph $2 .{ }^{123}$ For the Court: ${ }^{124}$

paragraphs 2 and 3 of Article 43 TFEU pursue different aims and each has a specific scope so that they can be used separately as a basis for adopting particular measures under the CAP, provided that the Council, when it adopts measures on the basis of

118 In contrast to other meetings of the Council, whose meetings are prepared by the Committee of Permanent Representatives, meetings of the Council composed of Ministers of Agriculture are prepared by the Special Committee on Agriculture (SCA), which was created by a decision of the representatives of the governments of the Member States in 1960. The SCA is composed of senior officials who are responsible for agricultural policy either in the Member States' permanent representations or in their ministries.

119 Case C-113/14, available at https://eur-lex.europa.eu/legal-content/EN/TXT/ PDF/?uri=CELEX:62014CJ0113\&rid=1.

120 Germany also sought the annulment of Article 2 of Regulation 1370/2013 ([2013] OJ L 346/12) determining measures on fixing certain aids and refunds related to the common organization of the markets in agricultural products.

121 Above n 119, para 37.

122 Ibid, paras 41 and 42.

123 Ibid, paras 44 to 50.

124 Ibid, para 58. 
Article 43(3) TFEU, acts within the limits of its powers and, where relevant, within a legal framework already established under Article 43(2) TFEU.

So, measures which involve a policy choice by the EU legislature (i.e. Parliament and Council) should be adopted under Article 43(2). Article 43(3) is thus reserved for measures by the Council which are necessary for the pursuit of the objectives set and achievable through the measures listed in that paragraph. As Article 7 of Regulation 1308/2013 fell within the latter category of measures, it should have been adopted under Article 43(3), especially as it involved technical and scientific assessments rather than political decisions. ${ }^{125}$

Reflecting on the legislative power to implement the CAP, the Court in Roquette noted: ${ }^{126}$

When the implementation by the Council of the agricultural policy of the Community involves the need to evaluate a complex economic situation, the discretion which it has does not apply exclusively to the nature and scope of the measures to be taken but also to some extent to the finding of the basic facts inasmuch as, in particular, it is open to the Council to rely if necessary on general findings. In reviewing the exercise of such a power the Court must confine itself to examining whether it contains a manifest error or constitutes a misuse of power or whether the authority in question did not clearly exceed the bounds of its discretion.

In other formulations of the scope of the legislative powers, the Court has indicated that 'political responsibilities' are imposed on the institutions by Articles 40 and 43. ${ }^{127}$ Similar characterizations have been made of the power of the Commission in those cases in which it has been delegated the power to implement legislation. ${ }^{128}$ Although the Court has given a wide interpretation to the concept of 'implementation', there are limits which must be respected. ${ }^{129}$ In this respect, the Court has noted: ${ }^{130}$

Since only the Commission is in a position to keep track of agricultural market trends and to act quickly when necessary, the Council may confer on it wide powers in that sphere. Consequently, the limits of those powers must be determined by reference to the essential general aims of the market organization. However, it must be pointed out that such a wide interpretation of the Commission's powers

125 Ibid, para 71. The Court went on to declare Article 7 severable from the rest of the Regulation.

126 Above n 117, 3358-3359.

127 See, for example, Case 138/78 Stölting [1979] ECR 713, Cases C-267-285

Wuidart [1990] ECR I-435 and Case C-343/07 Bavaria and Bavaria Italia [2009] ECR I-5491.

128 See, for example, Case 78/74 Deuka [1975] ECR 421, 432.

129 See, for example, Case 57/72 Westzücker [1973] ECR 231.

130 Case 22/88 Vreugdenhil [1989] ECR 2049, 2080. 
can be accepted only in the specific framework of the rules on agricultural markets. It cannot be relied upon in support of provisions adopted by the Commission on the basis of its implementing powers in agricultural matters where the purpose of the provision in question lies outside that sphere but within a sector subject to an exhaustive set of rules laid down by the Council which, moreover, do not confer any implementing powers on the Commission.

In this particular case, the legislation at issue dealt with customs law rather than agricultural law, so the Commission did not have the necessary powers. The Court was asked in Köster whether Commission consultation on implementing acts with a committee representing national interests (i.e. the Management Committee procedure) was compatible with various provisions of the Treaty of Rome, including Article 43(2). In response, the Court noted that: ${ }^{131}$

Both the legislative scheme of the Treaty, reflected in particular by the last indent of Article 155, and the consistent practice of the Community institutions establish a distinction, according to the legal concepts recognized in all the Member States, between the measures directly based on the Treaty itself and derived law intended to ensure their implementation. It cannot therefore be a requirement that all the details of the regulations concerning the common agricultural policy be drawn up by the Council according to the procedure in Article 43. It is sufficient for the purposes of that provision that the basic elements of the matter to be dealt with have been adopted in accordance with the procedure laid down by that provision. On the other hand, the provisions implementing the basic regulations may be adopted according to a procedure different from that in Article 43, either by the Council itself or by the Commission by virtue of an authorization complying with Article 155.

It concluded that the implementing legislation did not go beyond the limits of the implementation of the principles of the basic regulation and did not interfere with the Commission's right of decision or jeopardize its independence, as the Management Committee acted as a permanent consultation mechanism between the Council and the Commission. ${ }^{132}$ The Court also dismissed the objection to the procedure on the grounds that it deprived the Court of certain of its functions.

The Treaty of Lisbon has now formalized the rules on both delegated and implementing acts. Article 290 TFEU provides that the Commission may

\footnotetext{
131 Case 25/70, [1970] ECR 1161, 1170.

132 See also Case 46/86 Romkes [1987] ECR 2671, in which it was pointed out that an implementing regulation adopted without consultation of the European Parliament must respect the basic elements laid down in the basic regulation after consultation of the European Parliament. (2686) For a history in this area, see Bergström C Comitology: Delegation of Powers in the European Union and the Committee System (OUP, 2005).
} 
adopt delegated acts - that is, 'non-legislative acts of general application to supplement or amend certain non-essential elements of the legislative act'. The primary legislation will define the objectives, content, scope and duration of the delegation of power; the European Parliament and the Council have the power to revoke the delegation. The essential elements of an area shall be reserved for the legislative act and accordingly shall not be the subject of a delegation of power; this is in keeping with the jurisprudence of the Court. ${ }^{133}$ Delegated acts will enter into force if no objection has been expressed by the European Parliament or the Council within a period set by the legislative act. Article 291 TFEU allows for implementing acts by the Commission when 'uniform conditions for implementing legally binding Union acts are needed', with the rules and general principles for the Commission's exercise of implementing powers being set down in a regulation adopted by the European Parliament and the Council using the ordinary legislative procedure. ${ }^{134}$ It appears that the distinction between these two types of act rests with the question of whether an act amends or supplements a legislative act. If it does, it is a delegated act; but if it does not, it is an implementing act. ${ }^{135}$

Using Regulation 1308/2013, the common organizations regulation, as an example, the Commission is given power to adopt delegated and implementing acts across an extensive range of areas, including: ${ }^{136}$

- common provision on public intervention and aid for private storage (Articles 19 to 21);

- school fruit and vegetable scheme (Articles 24 and 25);

- school milk scheme (Articles 27 and 28);

- aid in the olive oil and table olives sector (Articles 30 and 31);

- aid in the fruit and vegetable sector (Articles 37 and 38);

133 See, for example, Case 23/75 Rey Soda [1975] ECR 1279, Cases 103-109/78 Société des Usines de Beauport [1979] ECR 17 and Case C-240/90 Germany v Commission [1992] ECR I-5383.

134 For a discussion of Article 291, see Case C-65/13 European Parliament $v$ Commission [2014] ECR I-2289 and its earlier jurisprudence in Case 16/88 Commission $v$ Council [1989] ECR 3457.

135 COM (2016) 799 Proposal for a Regulation of the European Parliament and of the Council adapting a number of legal acts providing for the use of the regulatory procedure with scrutiny to Articles 290 and 291 of the Treaty on the Functioning of the European Union and COM (2016) 798 Proposal for a Regulation of the European Parliament and of the Council adapting a number of legal acts in the area of Justice providing for the use of the regulatory procedure with scrutiny to Article 290 of the Treaty on the Functioning of the European Union. See also the Interinstitutional Agreement on Better Law-Making [2016] OJ L 123/1 and Case C-427/12 Commission $v$ European Parliament and the Council [2014] ECR I-170.

136 OJ 2013 L 347/671. 
- $\quad$ support programmes in the wine sector (Article 53 and 54);

- $\quad$ aid in the apiculture sector (Articles 56 and 57);

- $\quad$ aid in the hops sector (Articles 59 and 60);

- management of the authorization scheme for vine plantings (Articles 69 and 70);

- designations of origin and geographical indications in the wine sector (Articles 109 to 111);

- traditional terms in the wine sector (Articles 114 to 116);

- labelling and presentation in the wine sector (Articles 122 and 123);

- $\quad$ specific measures in the sugar sector (Articles 132 and 133);

- system of production regulation in the sugar sector (Articles 143 and 144);

- producer organizations and inter-branch organizations (Articles 173 to 175);

- trade with third countries (Articles 177 to 179);

- tariff quota management and special treatment of imports by third countries (Articles 186 to 188); and

- $\quad$ export refunds (Articles 202 to 204).

Article 227 of Regulation 1308/2013 provides that the power to adopt delegated acts is conferred for a period of seven years beginning on 20 December 2013 - the Regulation itself did not enter into force until 1 January 2014 - with the Commission drawing up a report on the delegation of power no later than nine months before the end of this period. Paragraph 3 confirms that the European Parliament or the Council may revoke the power at any time, with the previous paragraph noting that the delegation of power is to be tacitly extended for seven-year periods, unless the European Parliament or the Council opposes such extension no later than three months before the end of each period. Paragraph 4 provides that as soon as it adopts a delegated act, the Commission shall notify it simultaneously to the European Parliament and to the Council; and paragraph 5 notes that the delegated act will enter into force only if within two months of notification no objection has been expressed by either the European Parliament or the Council, or if within that period both institutions inform the Commission that they will not object. ${ }^{137}$ Article 228 provides that delegated legislation may enter into force without delay so long as no objection is raised by the European Parliament and the Council, which are to be informed of the reasons for the use of the urgency procedure. If an objection is raised by either body to the delegated act, the Commission is to repeal the act.

137 That period shall be extended by two months at the initiative of the European Parliament or of the Council. 
The final provision of this Chapter of the Regulation, Article 229, provides that the Commission will be assisted by a committee called the Committee for the Common Organisation of the Agricultural Markets. This Committee had its origins in Regulation 1234/2007, which established a single common organization of agricultural markets with a single Committee, replacing the sector-specific Committees that had previously existed. ${ }^{138}$ This is one of a number of agricultural Committees assisting the Commission, the others being:

- the Rural Development Committee; ${ }^{139}$

- the Committee on the Agricultural Funds; $;{ }^{140}$

- the Committee for Direct Payments; ${ }^{141}$

- the Agricultural Product Quality Policy Committee; ${ }^{142}$

- the Regulatory Committee on Organic Production; ${ }^{143}$

- the Committee on Agricultural Structures and Rural Development; ${ }^{144}$

- the Community Committee for the Farm Accountancy Data Network: ${ }^{145}$

- the Implementation Committee on Aromatised Wine-based Drinks; ${ }^{146}$

- the Committee for Spirit Drinks; ${ }^{147}$

- the Committee on the Conservation, Characterisation, Collection and Utilisation of Genetic Resources in Agriculture; ${ }^{148}$ and

- the Standing Forestry Committee. ${ }^{149}$

Each of these Committees is a 'committee' within the meaning of Regulation $182 / 2011$, which lays down the rules and general principles concerning

138 Regulation 1234/2007, [2007] OJ L 299/1, which in Article 195(1) established the Management Committee for the Common Organisation of Agricultural Markets and Article 195(3) established a Regulatory Committee.

139 See Article 84 Regulation 1305/2013, [2013] OJ L 347/487.

140 See Article 116 Regulation 1306/2013, [2013] OJ L 347/549. See also Article 41 of Regulation 1290/2005 on the financing of the CAP, [2005] OJ L 209/1.

141 See Article 71 Regulation 1307/2013, [2013] OJ L 347/608

142 See Article 57 Regulation 1151/2012, [2012] OJ L 303/1. This Committee replaced the Standing Committee on Protected Geographical Indications and Protected Designations of Origin and the Standing Committee on Traditional Specialities Guaranteed.

143 See Article 37 Regulation 834/2007, [2007] OJ L 189/1.

144 See Article 47(6) Regulation 1260/1999, [1999] OJ L 161/1.

145 See Article 18 Regulation 1217/2009, [2009] OJ L 328/27.

146 See Article 12 Regulation 1601/91, [1991] OJ L 149/1.

147 See Article 9(1) Regulation 110/2008, [2008] OJ L 39/16.

148 See Article 15 Regulation 870/2004, [2004] OJ L 162/18.

149 See Article 3 Decision 89/367, [1989] OJ L 165/14. 
mechanisms for control by Member States of the Commission's exercise of implementing powers. ${ }^{150}$

This Regulation notes that the basic act provides for the application of either an advisory or an examination procedure, with Article 2(2) providing that the latter will apply to implementing acts of general scope and implementing acts relating to the CAP. ${ }^{151}$ Article 2(3) provides that even if the examination procedure is mandated, the advisory procedure may be used in 'duly justified' cases, but the Regulation offers limited guidance as to when this threshold is met, so it could perhaps even allow the Council to adopt implementing acts. ${ }^{152}$ Unlike the advisory procedure, in which voting is by simple majority of the members, Article 5 on the examination procedure indicates that the weighted voting system will apply. In the event that a negative opinion is delivered, the Commission may resubmit an amended version of the implementing act within two months or within one month may submit the proposal to the Appeal Committee established under Article 6. If the negative opinion relates to an implementing act which needs to be adopted without undue delay (e.g. to avoid creating a significant disruption of agricultural markets), Article 7 provides that in this exceptional case, the Commission may adopt a draft implementing act. The adopted act must be submitted immediately by the Commission to the Appeal Committee and if it delivers a negative opinion, the implementing act will be repealed immediately. Article 8 provides that the Commission may adopt the act in cases of urgency, which will apply immediately and remain in force for a period not exceeding six months unless the basic regulation provides otherwise. The Commission is required to submit the act to the relevant committee within 14 days and in the event of a negative opinion, the implementing act is to be repealed immediately.

The Regulation applies to implementing acts (Article 291 TFEU) as Article 290 sets out a different procedure for the adoption of delegated acts: these provisions are mutually exclusive. This bifurcation of procedure makes it essential that the Commission abide by the distinction between these two types of act in its proposals, and that the European Parliament exercise oversight over the

150 [2011] OJ L 55/13. See also Commission notice on the standard rules of procedure for committees [2011] OJ C 206/11. For an excellent discussion of the Regulation, see Craig P 'Delegated acts, implementing acts and the new comitology regulation' (2011) 36 ELRev 671. See also Schütze R “"Delegated” legislation in the (new) European Union: a constitutional analysis' (2011) 74 MLR 661.

${ }_{151}$ The 2016 Commission Report on the implementation of Regulation 182/2011 (COM (2016) 92) indicates that of around 1500 acts, fewer than 10\% were adopted using the advisory procedure ( $\mathrm{p} 7)$.

${ }_{152}$ See Peers S and Costa M Accountability for delegated and implementing acts after the Treaty of Lisbon' (2012) 18 European Law Journal 427, arguing that this would subvert Articles 290 and 291 TFEU. 
distinction as it is given a greater role with respect to delegated acts. However, Article 11 of Regulation 182/2011 allows the European Parliament or the Council to indicate that it considers the implementing act exceeds the powers in the basic regulation adopted under the ordinary legislative procedure. While the Commission is not obliged to withdraw the act, it does have a duty to take the views of these institutions into account in a review of the draft act, after which it will inform the European Parliament and the Council whether it intends to maintain, amend or withdraw the draft implementing act.

The 2016 Commission Report indicated that in 234 instances there was no opinion in the examination procedure, with the Commission adopting the measure in 222 cases; and that there were 36 referrals to the Appeal Committee from 2011 to 2014, with no opinion being delivered by the Committee in 31 instances. ${ }^{153}$ This latter statistic involved a number of measures relating to the health and safety of humans, animals and plants which prompted the Commission in 2017 to propose four specific amendments to Regulation $182 / 2011$ to improve the functioning of the appeal committee that would reduce the number of situations in which it delivered no opinion. ${ }^{154}$ The first of these was a change to the voting rules by considering Member States which are not present, or which abstain, as 'non-participating Member States' in the calculation of the qualified majority. The second change would involve a further appeal committee meeting at ministerial level for particularly sensitive cases; in most cases Member States are represented by their Permanent Representatives. The third change would involve making public the votes of Member States within the appeal committee, with the final change allowing for the matter to be referred to the Council for a non-binding opinion. A decision has yet to be made on these proposed amendments.

Tilly-Sabco was an action for annulment brought against a Commission Implementing Regulation fixing export refunds on poultry meat which the applicant alleged breached an essential procedural requirement - namely, failure to comply with Regulation 182/2011 - which had been dismissed by the General Court. ${ }^{155}$ The Court (of Justice) pointed to Article 291(3) as a control on the exercise of the Commission's exercise of implementing powers and

\footnotetext{
153 Above n 151, pp 5 and 6.

154 COM (2017) 85. These included a number of measures authorizing genetically modified organisms and genetically modified food and feed.

155 Case C-183/16 P, judgment of 20 September 2017, available at https://eur-lex .europa.eu/legal-content/EN/TXT/PDF/?uri=CELEX:62016CJ0183\&rid=1. See Case T-397/13 Tilly-Sabco, judgment of 14 January 2016, available at https://eur-lex.europa .eu/legal-content/EN/TXT/PDF/?uri=CELEX:62013TJ0397\&rid=3.
} 
Regulation 182/2011 as the control mechanism. Looking at the time limits set out in Article 3(3) of the Regulation, the Court noted: ${ }^{156}$

it must be held that the first time limit is to enable an unhurried examination of a draft implementing act before a meeting, by the Management Committee members, and that the second must enable them to express their views on the draft. That finding is supported by Article 3(4) of Regulation 182/2011 which states that, 'until the committee delivers an opinion, any committee member may suggest amendments'. Furthermore, since Article 291(3) TFEU expressly provides for control by Member States of the Commission's exercise of implementing powers conferred on it by paragraph 2 of that article, it must be held that the first time limit also aims to guarantee that the governments of the Member States are informed through their Management Committee members about the Commission's proposals, so that those governments may, by means of internal and external consultations, define a position in order to protect the specific interests of each of them within the Management Committee.

In this particular case, the proposal was submitted in its final form during the meeting, which the Court found to be incompatible with the wording and objectives of Article 3(3), which were essential procedural requirements. ${ }^{157}$ The Regulation was thus annulled.

As already noted, the Court usually accords the institutions a very wide discretion in cases dealing with the scope of the EU's legislative power to implement the CAP. ${ }^{158}$ For example, in Westzücker it stated: ${ }^{159}$

It is consonant to the very idea of the [EU] that, within the framework of the mechanism of collective discussion set up with a view to the implementation of the common agricultural policy, the Member States should emphasise their interests, whilst it falls to the Commission to arbitrate, through the measures taken by it, between possible conflicts of interest from the point of view of the general interest.

By necessary implication, this 'arbitration' by the Commission allows it to take into account all the considerations highlighted in Articles 38 to 44 that would impact on the implementation of the policy. So, the discretion allowed by the Court permits the EU institutions to balance the economic, social and

156 Ibid, paras 102 and 103. In para 108 the Court rejected the risk of leaks, which was the Commission's justification for failure to abide by the time limits.

157 Ibid, para 105. The Court also held it to be incompatible with Articles 8 (para 106) and 3(4) (para 107).

158 Cases 83 and 94/79 HNL [1979] ECR 1209. This wide discretion also extends to the conditions justifying Community financial assistance under various rural development initiatives. See generally, Cases C-258/90 and C-259/90 Pesquerías de Bermeo [1992] ECR 2901 and Case T-465/93 Murgia Messapica [1994] ECR II-361.

159 Case 57/72 [1973] ECR 321, 341. The Court has frequently repeated this comment. 
monetary considerations addressed in this part of the Treaty, thus recognizing their political responsibilities. This implication was subsequently confirmed by the Court when it noted that 'in matters concerning the common agricultural policy, the EU legislator has a discretionary power which corresponds to the political responsibilities imposed by' Articles 40 and $43 .{ }^{160}$ As a result, the role of the Court in reviewing agricultural legislation is limited to 'examining whether it contains a manifest error or constitutes a misuse of power or whether the authority in question did not clearly exceed the bounds of its discretion'. ${ }^{161}$

As already noted, the one area in which the Court is likely to intervene is in questions relating to the use of Article 43 as the proper (and sole) legal basis for a particular measure. For example, in the past EU legislation on health measures in agriculture has used Article 43 as its legal base and this has been approved by the Court. ${ }^{162}$ Such measures, according to the Court, remain within the scope of Article 43 if they are concerned with Annex I products and are intended to achieve one or more of the objectives of Article 39. ${ }^{163}$ Logically, therefore, if the scope of the measure extends beyond these two conditions, then another legal base will be needed for the particular measure. However the Court in Commission and European Parliament $v$ Council endorsed the use of Article 43 as a sole legal base for EU health measures even though it could have been based on Article 168 TFEU, which requires that health protection form part of all EU policies. ${ }^{164}$ It is worth noting here that the regulation at issue in this dispute, Regulation 820/97, has now been replaced by a Regulation adopted with a dual legal base, and that this pattern has been repeated elsewhere. ${ }^{165}$ Such a trend suggests that the objectives of the CAP are being attuned to reflect increasing consumer concerns about agriculture, thus

160 For example, in Case 265/7 Schräder [1989] ECR 2237, 2270.
161 Case 138/97 Roquette [1980] ECR 3333, 3358-3359. See also Joined Cases C-267/88 to C-285/88 Wuidart [1990] ECR I-435, where the Court stated that the Community institutions were obliged 'in connection with the adoption of rules, to assess their future effects, which cannot be accurately foreseen, its assessment is open to criticism only if it appears manifestly incorrect on the light of the information available at the time of adoption of the rules in question'. (481). See also Case T-257/07 France v Commission [2011] ECR II-5827, paras 84 and 85 for later cases with similar conclusions.

162 See, for example, Case 68/86 United Kingdom v Council [1988] ECR 855 and Case 131/86 United Kingdom v Council [1988] ECR 905.

163 Case 131/87 Commission v Council (Glands) [1989] ECR 3743. See also Case 11/88 Commission v Council (Pesticides) [1989] ECR 3799.

164 Case C-269/97 [2000] ECR I-2257.

165 Regulation 1760/2000, [2000] OJ L 204/1. See also Regulation 999/2001 on transmissible spongiform encephalopathies, [2001] OJ L 147/1 and Directive 2001/10 on scrapie, [2001] OJ L 147/41. In 2005 the Court upheld the use of Article 152 as a joint legal base for the adoption of Directive 2002/2 on the circulation of compound 
promoting a more multifunctional approach to agriculture in the European Union.

\title{
5. CONCLUSIONS
}

In 2005 the Commission published a Communication on Simplification and Better Regulation for the Common Agricultural Policy, which noted that: ${ }^{166}$

\begin{abstract}
Since its introduction the CAP has established a comprehensive political and legal framework for European agriculture; as a fully integrated common policy it replaces a significant amount of national legislation. It has largely accomplished the objectives set out in the EC Treaty while cushioning the social impact of agricultural restructuring. As a corollary farmers and administrations have to deal with a dense set of rules and measures, which may increase the risk of failing to meet policy objectives, make it more difficult to ensure sound expenditure of EU funds and diminish acceptance of CAP measures.
\end{abstract}

Simplification would involve a revision of the legal framework, administrative procedures and management mechanisms to promote more effective realization of existing policy objectives (characterized as technical simplification) and an improvement in agricultural support and rural development policy instruments (policy simplification). The Communication, which focused on technical simplification, noted that it had to be compatible with broader policy objectives such as the environment and food safety - in other words a balance had to be struck between having a common policy to respect the single market, undistorted competition and the liberalization of trade on the one hand, and the diversity of the agricultural situations in all Member States on the other.

Since the Communication, there has been a simplification at both the technical level and the policy level. For example, the CAP is now governed by four major legal instruments: the Regulations on Direct Payments, Rural Development, Finance and a Common Organisation of the Markets. Each of these Regulations is examined in the next four chapters of this work, with the final chapter being devoted to the proposals for the future shape of the CAP in the next Multiannual Financial Framework (2021-2027). These proposals are of considerable interest, as they suggest that the future of the policy rests on realizing a different balance between what is common (i.e. regulated at the EU level) and what is national. While a re-nationalization of agricultural policy is not envisaged in these proposals, the process of simplification is set to continue.

feedingstuffs, see Joined Cases C-453/03, C-11/04, C-12/04 and C-194/04 ABNA and others [2005] ECR I-10423.

166 COM (2005) 509, p 1. 